\section{Farm products' direct sale in accordance with national and EC Regulations}

\author{
Massimo Renato Micheli, ${ }^{1}$ \\ Alfredo Rossi, ${ }^{2}$ Giovanni Rossi, ${ }^{3}$ \\ Alfonso Rosamilia, ${ }^{4}$ Emanuele Guidi ${ }^{1}$ \\ ${ }^{1}$ Local Sanitary Authority of Modena; \\ ${ }^{2}$ Local Sanitary Authority of Benevento; \\ ${ }^{3}$ Local Sanitary Authority of Parma; \\ ${ }^{4}$ Institute for Experimental Veterinary \\ Medicine of Abruzzo and Molise, \\ Teramo, Italy
}

\section{Abstract \\ Primary production has always been} considered the weak link in the entire food production chain (from farm to fork) and, due also to the grave health and food emergencies that have taken place over the years (BSE, dioxin, avian flu etc.), greater attention has been focused on the production stage, together with the need to regain the consumers' faith. To preserve and support small farms in a local setting and, consistent with the aims of flexibility and respecting the main requisites contained in the EC Regulations (No. 852/2004; No. 853/2004) (European Commission, 2004; 2004a), production is allowed for tastingadministration on the premises and the processing and sales of agricultural products produced exclusively on the farm, such as: fresh meat from poultry and rabbits and small farmed wild animals; processed meats obtained from animals raised on the farm and from hunting; fishing and aquaculture products; raw milk for direct human consumption and dairy products; eggs, honey, fruit and vegetables, woodland products; jams and preserved fruit, flours, vegetable preserves, wild above ground and underground mushrooms; dried fruits, fruit juices, cereals, syrups; oil, wine, bread and baked products. This possibility is reserved for individual farmers or co-operatives, registered in the company register according to Article 8 of the Law 29th December 1993 No. 580 (Italian Republic, 1993); who may sell directly inside and outside farm, products coming mainly from the respective farms, observing the current regulations regarding health and hygiene. All this should provide an instrument for rural and competitive development for the entire European agricultural production chain strongly influenced by the marketing conditions imposed by the mass retailing groups on their own suppliers. Not least is the possibility of creating work and occupation and adequately counteracting the phenomenon of the depopulation of the countryside, encouraging the return to agricultural activities on the part of young people; and, consequently, a form of safeguarding the environment by reducing the costs linked to hydro-geological instability and soil maintenance. This trend, together with the national directions, may represent a support even for small local farms which, taking advantage of simplified procedures consistent with the objectives of flexibility of the community Regulations (EC) (No. 852/2004; No. 853/2004) (European Commission, 2004; 2004a), may take part in the promotion of agricultural markets managed directly by the farmers as sales points for local products (farmers' markets), so as to guarantee a fairer price and consolidate the territorial link between production and consumption (short distribution chain or short circuit). Without, of course, renouncing the necessary prerequisites for placing any food on the market: health-hygiene; traceability; health and well-being of the animals; safeguarding of the environment and the plants.

\section{Introduction}

With reference to the hygiene and health, primary production, as defined by Article (Art.) 3 of the Regulation (EC) No. $178 / 2002$, includes all the stages of the production, rearing or growing of primary products including harvesting, milking and farmed animal production prior to slaughter and also includes hunting and fishing and the harvesting of the wild products (European Commission, 2002).

Primary production is subject to notification (notification start certified reporting) according to Art. 6 of the Regulation (EC) No. 852/2004, and consequently registration by the competent Authority.

Departing from the requirements laid down by the Regulation (EC) No. 852/2004, there is "the direct supply, by the producer, of small quantities of primary products to the final consumer or to local retail establishments directly supplying the final consumer" (European Commission, 2004).

In this context the direct supply retail activities carried out by holiday farms are included and for these the market regulations are those laid down by the regulations in the sector (State-Region Agreement (SRA) No. 59/CSR of 29/4/2010) (Italian Republic, 2010). The same Agreement lays down what is meant by "direct supply", "retail marketing", "Local level" and "small
Correspondence: Massimo Renato Micheli, Local Sanitary Authority of Modena, Italy. Tel.:+39.0592.134742; Fax +39.059.3963757 E-mail:m.micheli@ausl.mo.it

Key words: farmer, direct sales, farmers' markets.

Contributions: the authors contributed equally.

Conflict of interest: the authors declare no potential conflict of interest.

Funding: none

Received for publication: 4 October 2017

Revision received: 17 September 2018.

Accepted for publication: 12 November 2018.

This work is licensed under a Creative Commons Attribution-NonCommercial 4.0 International License (CC BY-NC 4.0).

(C) Copyright M.R. Micheli et al., 2019

Licensee PAGEPress, Italy

Italian Journal of Food Safety 2019; 8:7119

doi:10.4081/ijfs.2019.7119

quantities". The farm activities set down in Art. 2135 of the Civil Code are carried out by the professional farmer (Legislative Decree No. 99/2004, Art. 1) (Italian Republic, 2004) which includes both individual persons and companies made up of people, co-operatives and capital, if the statute allows that subject the exclusive right to agricultural activities as well as other special conditions.

As well, there is the small agricultural farmer or direct producer, understood as the person who cultivates the farm with his own work and that of his family, given that this work force makes up at least a third of that necessary for the normal cultivation of the land (Law No. 353/1949, Art. 1, paragraph 3 (p); Law No. 203/1982, Art. 6) (Italian Republic, 1949; 1982).

Personal participation is essential to the definition of farmer in farming work together with the right to the management of the land production.

The operations associated with agriculture are those "concerning handling, preservation, processing, marketing and promotion which regard products obtained principally from land cultivation or in woods or animal rearing; as well as activities concerning supply of goods and services mainly using equipment or resources of the company normally used in the agricultural activity carried out, including the activities of rural, forest and territorial heritage promotion, that is reception and hospitality as defined by the law" (Legislative Decree 
18 May 2001, No. 228) (Italian Republic, 2001). The production and direct marketing of processed agricultural products of animal origin (secondary milk products, meat based products etc.) departing from the Regulation (EC) No. 853/2004 "when the supply of foodstuffs of animal origin is carried out only by a laboratory connected to the retail establishment to another premises connected to the retail outlet and, according to national legislative provisions, this supply represents a marginal, localized and restricted activity" (Regulation (EC) No. 853/2004, Art. 1, p 5, point b, ii,) (European Commission, 2004b). The SRA of 17/12/2009 makes the field of application clear regarding the Art. above (No. 253/CSR) (Italian Republic, 2009).

\section{Aim of the paper}

The purpose of this paper is to provide a general overview of European and national legislation on the marketing of primary production foodstuffs.

\section{Production and marketing}

\section{Meat from poultry and lagomorphs (rabbits, hares and rodents)}

The Regulation (EC) No. 853/2004 (Art $1, \mathrm{p} 3$, letter d) allows, making an exception, the "direct supply, by the producer, of small quantities of meat from poultry and lagomorphs slaughtered on the farm to the final consumer or to local retail establishments directly supplying such meat to the final consumer as fresh meat" (European Commission, 2004b).

The small quantity of meat coming from and the poultry and the number of lagomorphs slaughtered on the producer's farm are laid down by the SRA 17/12/2009 as a maximum of $50 \mathrm{UBE} /$ year made up of poultry, lagomorphs and small farmed game (1 UBE-Unit Bovine Equivalent $=200$ hens or 125 rabbits) with respect to the requisites referred to in attachment II, Chapter 1, 2 and 5 point 1 of the Regulation (EC) No. $852 / 2004$, for supplying on the part of the producer, directly: i) to the final consumer; ii) to the laboratories attached to the retail or administration companies that supply directly to the final consumer these meats as fresh meats, found in the environment of the territory of the Province where the farm is set up or in the territory of neighboring Provinces.

This activity, however, falls within the field of application of the Regulation (EC) No. $852 / 2004$ and is subject to compulsory notification to the official authorities for registration (European Commission, 2004).

The Regions and Autonomous
Provinces, with their own regulations, can set down the maximum, most restrictive limit on the number of poultry and lagomorphs slaughtered on farms in their territory, as well as the methods of supplying to the final consumer, only by occasional and immediate direct request of small quantities of poultry and lagomorph meat slaughtered on the producer's farm, up to an overall maximum of 500 animals/year made up of poultry, lagomorphs and small farmed wild animals.

\section{Milk and dairy products}

The use of raw milk produced on the farm is allowed, for food purposes, as long as the requirements for food milk composition (Regulation (EC) No. 2597/1997) (European Commission, 1997) and the health-hygiene measures for marketing set down by the SRA 25/01/2007 are observed (direct sales or through vending machines outside of the farm) (Italian Republic, 2007); as well, mandatory information and measures must be provided to safeguard the consumer of raw milk or cream: "Product to be used after boiling" (Health Ministry Decree of 12/12/2012) (Italian Republic, 2012). Animals used for food milk production must also hold the health requirements set down by the Regulation (EC) No. 853/2004, section IX, chapter 1 point 4 . The sale of raw milk is also allowed for the production of milkbased products respecting the criteria of the above-mentioned Regulation (European Commission, 2004b).

\section{Eggs}

Eggs produced on a farm may be sold at the place of production as long as they are not packaged or classified Council Regulation (EEC) No. 1907/90 as amended by Regulation (EC) No. 1272/2008, Regulation (EU) No. 1308/2013 repealed Council Regulation (EC) No. 1234/2007 (code and farming system printed on the shell) is permitted (European Commission, 2008; 2013). As well, if they are sold directly from the producer to the final consumer at the place of production or near the production area in a local public market or door to door sales, the eggs need not be classified on the basis of quality and weight. The Decree (Ministerial Decree for Forest and Agricultural Food Policies of $11 / 12 / 2009$ ) specifies that only eggs sold in a public market place must, however, be marked with the producer's code with the exception of those coming from producers who have up to 50 egg-laying hens and on the condition that the name and address of the producer are shown at the sales point (sign) or communicated to the customer in the case of door to door sales (Italian
Republic, 2009). Lastly, regarding the sale of bulk unclassified eggs, the date of minimum durability must be written and this must not be more than 28 days after laying.

\section{Honey and other food products from bee-keeping}

Bee-keeping activities (raising bees, even at a distance from the bee-keeper's premises, the collection of honey, its centrifugation and the wrapping and/or packaging of the honey) carried out in the bee-keeper's premises is considered as primary production. Other operations outside the bee-keeper's premises (e.g. the centrifugation and/or wrapping/packaging of honey or its processing) cannot be considered as primary production, including those carried out on behalf of bee-keepers by collective establishments (e.g. Cooperatives) or their processing.

For the production of honey and other bee-keeping products (Royal jelly or honey, propolis, beeswax, pollen) every bee-keeper who is not already registered at the official veterinary service is obliged to declare the beginning of the bee-keeping activity and to ask for the assignment of an identifying code, valid for the whole national territory, and which will be assigned by the veterinary service of the Local Health Unit (LHU), on the basis of the legal premises of the beekeeper (Law No. 313/2004; Ministry of Health Decree of 11/08/2014) (Italian Republic, 2004; 2014). Honey put on sale must comply with the requirements laid down by the Legislative Decree No. $179 / 2004$ and be pre-packaged at the place of origin in hermetically sealed containers ("Guidance document on the implementation of certain provisions of Regulation (EC) No. 852/2004 on the hygiene of foodstuffs EUROPEAN COMMISSION HEALTH \& CONSUMERS DIRECTORATE GENERAL, Brussels, 18 June 2012”) (Italian Republic, 2004).

\section{Fish and aquaculture products}

The Legislative Decree No. 226/2001 defined the fish farmer, which is equivalent to an agricultural farmer although fishing activities take precedence. He is the person who carries out an activity aimed at capturing or harvesting aquatic organisms in seawater, salt-water or fresh water as well as the activities linked to this (Italian Republic, 2001). Among the activities linked to this, as in the case of agricultural farmers, hospitality and catering etc. are envisaged; and similarly, to holiday farms, there are recreational fishery farms. The Legislative Decree No. 226/2001 defined fish farmers as on a par with agricultural farmers. They carry out activities aimed at capturing or 
harvesting aquatic organisms in fresh, salty or sea water environments as well as the activities linked to this (Italian Republic, 2001). To improve his production, the fish farmer may also supply fish directly to the consumer in a local area with no intermediation. This is part of the normal activities according to Art. 2 of the Legislative Decree No. 4/2012 (Italian Republic, 2012). These sales as a special exemption to the Regulation (EC) No. $852 / 2004$ and No. $853 / 2004$ regulated by the SRA of the $05 / 11 / 2015$ which fixes the "small quantities" of the direct supply as a maximum of $100 \mathrm{~kg}$ per daily boat-load both for the final consumer and for the workshops annexed to the retail sales or administration companies which in their turn supply directly to the final consumer (Italian Republic, 2015). The territorial authorities (Town Council, Regional Maritime Domain, Port Authorities) may regulate at a local level the methods of direct supply of the primary product.

\section{Jams, fruit juices, fruit preserves, syrups, pickles, flours, vegetable preserves, mushrooms and dried fruits and vegetables}

These are products obtained by cultivation and processing fruit, cereal, mushroom and vegetable products or harvested by the primary producers themselves (Legislative Decree No. 77/1993). Currently for the marketing denomination for jams and preserves, the Legislative Decree No. 50/2004 must be referred to (Italian Republic, 1993; 2004).

\section{Mushrooms and woodland fruit products}

Apart from aboveground mushrooms and underground mushrooms (truffles) whose harvesting is controlled by special regional regulations, strawberries, raspberries, blueberries and juniper berries are considered as woodland fruit products. The regions have regulated in their own territories both the harvesting of wild aboveground mushrooms and truffles by granting special authorization for harvesting or collecting (license card). Special concessions are given to citizens who have the use of woods and for farmers who, even if they are owners of private harvesting or cultivation areas, must however, notify the SUAP (Unique Productive Activities Office) of their respective towns. The sale of the product must always be accompanied by the traceability document (Regulation (EC) No. 178/2002, Art. 18) (European Commission, 2002). The harvesting of wild mushrooms not carried out in a forestry area is not considered to be an agricultural activity; as well, for either direct sales or to caterers, the harvest must be certified by a trained mycologist from the Local Sanitary Authority (Mycology Office).

\section{Marketing of aboveground mush- rooms}

For the marketing of fresh wild mushrooms and/or dry, loose porcini mushrooms (Boletus edulis and related group), the Food Business Operator (FBO) must present a certified notice of commencement of the activity (Notification start certified reporting) to the Mayor of the town where the activity has its head office. The Notification start certified reporting, even when limited to the marketing of a single species, is presented by persons approved as eligible by the Department of Public Health of the LHU and responsible for identifying the species of mushroom marketed so that an adequate knowledge of the risks connected to this activity can be established. The Region, with this act, sets down the methods used to recognize the eligibility. For the retail of fresh wild mushrooms responsible staff who possess the appropriate eligibility may be used as needed.

\section{Marketing of fresh truffles}

Fresh truffles must belong to the species indicated in the attachment of Art. 2 of the Law No. 752/1985 and subsequent amendments and supplements (Italian Republic, 1985). In the Annex I of the same law, the botanical and organoleptic characteristics are also set down for the various species. When marketed, truffles must be classified by species and variety, be healthy and free from earth or other impurities; as well they must be kept separate from broken truffles (Pieces of truffles larger than $0.5 \mathrm{~cm}$ in diameter are considered to be "pieces"). The scientific name and the geographical area of provenance must be written on special signs both for whole fresh truffles and pieces.

\section{Olive oils and pomace olive oils}

Many farms feature growing olives for the production of olive oil. The product generally undergoes milling operations to obtain the oil at the oil mill. The places used as mills, whether or not they are part of the farm, must be registered according to Art. 6 of Regulation (EC) No. 852/2004 (European Commission, 2004). The Regulation (EC) No. 1531/2001 sets down the descriptions and definitions of the olive oils obtained directly from olives and by mechanical means (European Commission, 2001).

The sale of bulk oil from the mill or from the farmer is banned. The Ministry of Industry, with its own Circular No.
$165 / 2000$, points out that it is set down in Art. 7 of the Law No 35/68: "Olive oils destined for the consumer must be placed on sale exclusively wrapped in hermetically sealed containers" (Ministry of Industry, Circular No. 165/2000) (Italian Republic, 2000).

The oil mills, that is, the companies that carry out the milling of the olives, the companies that do the packaging, the bulk oil sellers, the refineries and lastly the contractors - those who carry out the production, processing and/or the deposit of oils for third parties - and olive residue treatment factories, all are obliged to keep the Nutrition and Food Hygiene Service Telematic "Provisional Registry". This is made available to all the users of the oil production chain to fulfil the requirements set down in the Decree of 23/12/2013 No. 16059 of the Ministry of Agricultural, Food and Forestry Policy (Regulation (EC) No. 1019/2002) (European Commission, 2002).

This obligation is those who keep exclusively oils, for example: a) used as ingredients in food products different from mixtures of oils treated in Art. 6, p 1, of the Regulation (EU) No. 29/2012 (for example, preserves under oil, sweets or baked products etc.) (European Commission, 2012); b) not destined for use in food (for example for the cosmetic industry, production of energy etc.) destined for their own consumption.

Vegetable oils, since they are processed products, cannot benefit from the exemption of having the nutritional table on the label (Regulation (EU) No. 1069/2011) (European Commission, 2011).

\section{Bread and bakery products, flours and pastries}

For bread the reference regulation is set down by the Law No. 580/1967 and subsequent amendments and supplements (Italian Republic, 1967). The term "bread" means the product by the total or partial cooking of a correctly leavened dough, prepared with grain flours, water and yeast, with or without the addition of common salt. Many types of bread can be offered for sale: "unbleached bread" produced with wheat flour; "0 type bread" with wheat flour type 0 ; "wholemeal bread" made with wholemeal flour; "bran bread" and "granulated bran bread" respectively made with semolina or granulated semolina from durum wheat. Bread must be made in places registered according to Regulation (EC) No. 852/2004 (European Commission, 2004). In the retail points the various types of bread must be placed in separate compartments, bearing a sign showing the type of bread and its price. For the various types of products the specific 
reference regulations are fresh bread, preserved bread or long-life bread (Law No. 248/2006) (Italian Republic, 2006); flours and food dough (Italian Decree No. 187/2001) (Italian Republic, 2001); production and marketing of bread (Decree No. 502/1998; Decree 22/07/2005 as well as the modification by the Ministerial Decree 14/06/2017) (Italian Republic, 1998; 2005; 2017): The sale of bulk bread is allowed in public areas (Order by the Health Ministry of 03/04/2002) in buildings and in mobile shops only when there are display counters which have suitable health and hygiene characteristics (Italian Republic, 2002). For bread that is not pre-packaged or generally sold after slicing for immediate sale, a special sign must be present on the container or displayed in the compartments where it is on sale. The following information must be shown on the sign: i) the marketing classification; ii) the list of ingredients except for those exempt; iii) the production company.

\section{Wine and wine products}

The current Regulations on this subject are set down by provisions from the community and by the national regulations (Italian Decree No. 162/1965; Law No. 164/1992) (Italian Republic, 1965; 1992). As well as wine we have various wine products: piquette (light wine), fortified wine, sparkling wine, grape musts, grapes juices etc. (Law No. 238/2016; Regulation (EU) No 251/2014; Regulation (EC) No. 110/2008; Regulation (EEC) No. 822/87) (European Commission, 1987; 2008; 2014; Italian Republic, 2016). For table wines produced outside the guidelines no information is required regarding the vine but only stating if it is white or red in color (Law No. 164/1992) (Italian Republic, 1992). Direct sales of wine, if admitted by the production guideline regulations, may be sold in bulk using containers belonging to the buyer. The parties concerned must inform the control structure about the quantities of wine coming from Protected Geographical Indications which are sold directly to the final consumer. The communications must be made by the fifth day of the month following the sales. The provisions and the tariff table are the responsibility of the seller. If the name or the address of the bottler, producer, importer or marketer contains or is made up of a protected origin name or a protected geographical indication, that name or address is displayed on the label (Regulation (EC) No. 607/2009, Art. 56) (European Commission, 2009). Wines and similar beverages are exempt from displaying the Minimum Durability and the use by date.

\section{Snails and Frogs' legs}

Both represent primary products destined for human consumption. They are harvest animals and can be farmed, in particular snails, but also frogs whose growth is favored in rice growing and fish farming areas. For both species the slaughter for the following handling and processing is governed by the requirements set down in Attachment III, Section XI of the Regulation (EC) No. 853/2004 (European Commission, 2004b).

On this subject, it is useful to remember that the Regulation (EC) No. 1099/2009, regarding the protection of animals during slaughtering, in specifying that by "animals" is meant "Any vertebrate animal, excluding reptiles and amphibians" excludes both frogs and snails from its field of application (European Commission, 2009).

Regarding snail farming, a manual of good working practices exists approved by the Ministry of Health of $15 / 02 / 2016$; while the Ministry for Forest and Agricultural Food Policies has issued the "National Regulations for ecological snail farming recognized according to Art. 42 of the Regulation (EC) No. 834/2007 and subsequent amendments and supplements" (European Commission, 2007; Italian Republic, 2016).

\section{Direct supply methods}

The national standards for organic snail farming have always allowed direct retail selling of agricultural products on the part of farmer-producers, unless there are regulations on the subject of health and hygiene. These regulations are also applied in the case of sales of secondary products obtained following handling or processing activities of the agricultural products and products of animal origin, aimed at complete exploitation of the production cycle of the farm (Legislative Decree No. 228/2001, Art. 4, p 5) (Italian Republic, 2001).

Regarding the most recent simplification in agriculture "in the area of direct sales the immediate consumption of the products being sold is allowed, using the premises and equipment available to the farmer, with the exclusion of assisted administration service and by observing the general regulations of a health-hygiene nature" (Legislative Decree No. 228/2001, p 8-bis, as introduced by the Decree Law No 69/2013, converted into Law 9 August 2013 No. 98) (Italian Republic, 2001; 2013).

Facilitations have also been introduced for the premises where the activity of direct sales of the agricultural products takes place when the change of destination of use of the premises is not necessary. As well, the sales can be carried out over the whole town council territory regardless of the urban purpose of the zone in which the premises intended for this are situated. (Therein, $p 8$ ter). As well as the activity of marketing primary products produced by themselves, the Legislative Decree No. 228/2001 allows the sale of agricultural products coming from other farms, as long as they are not in the majority portion, at their own farms in appropriately equipped premises and, if necessary, registered with the appropriate authority and on outdoor surfaces. Farmers can also carry out sales at a distance by travelling around to markets or farmers' markets and other methods (Italian Republic, 2001). For the sale of primary products on outdoor surfaces in the farm area or in other private areas that the farm has available, neither the Notification start certified reporting nor notification is necessary according to the Regulation (EC) No. $852 / 2004$, while the Notification start certified reporting is sufficient according to the Legislative Decree No. 228/2001 if such products are sold travelling around/itinerant markets or in a farm room specially set up for the purpose (European Commission, 2004; Italian Republic, 2001).

For direct supply carried out from the farm, as well as for selling carried out during festivals, fairs, or shows of a religious, charitable or political nature or for promoting typical or local products, reporting the start of the activity is not requested. (Legislative Decree No. 228/2001, Art. 4, c. 2) (Italian Republic, 2001).

\section{Selling in public areas}

The Legislative Decree No. 228/2001, in Art. 4, allows farmers, either individually or associates, the retail sale of products coming for the most part from their respective farms, respecting the current regulations regarding health and hygiene (Italian Republic, 2001).

The "guidelines for setting up markets reserved for direct sales on the part of farmers referred to in Art. 2135 of the Civil Code, which includes farmers' cooperatives" (Decree by the Ministry for Forest and Agricultural Food Policies of 20/11/2007, Art. 1 and 2) state that "in farmers' markets with direct sales conforming to the health and hygiene regulations set down in the EC Regulation No. 852/2004 and subject to the related controls on the part of the competent authorities, only agricultural products conforming to the current regulations for individual products may be placed on sale showing the place of territorial origin and the production company" (Italian Republic, 2007). From a health point of view regarding 
sales in public areas, the special regulation is the Order of the Health Ministry $03 / 04 / 2002$, except for regional regulations on the subject where these are not in conflict with the European Regulations (Regulation (EC) No. 852/2004, attachment II, chapter III) (Italian Republic, 2002).

Art. 30 of the Legislative Decree No. 114/1998 (regulation concerning the marketing sector) though it excludes from its field of application farmers, share-croppers and settlers who sell their products in public areas according to the Law No. 59/1963 subsequent amendments and supplements, sets out the methods and the criteria for assigning areas reserved for farmers who sell their products (Italian Republic, 1963; 1998).

If retail selling is to be carried out, not in an itinerant form, in public places or in places open to the public, the request is addressed to the Mayor of the Town Council where the sales are to be held. (Legislative Decree No. 228/2001, Art. 4) (Italian Republic, 2001). For retail sales in public places using a stand site, the notification must contain the request for assignment of the stand-site. (Legislative Decree No. 114/1998, Art. 28) (Italian Republic, 1998).

Note that itinerant marketing of fresh, wild, above ground mushrooms is, however, forbidden. These may be sold with mycological certification and only in market areas; as well, the FBO must have the relevant Notification start certified reporting notification at the start of the activity with the relevant certification of competency issued by the official territorial LHU.

\section{Internet sales (e-commerce)}

Among the marketing activities that farmers may carry out there is also ecommerce. This type of direct sales may be started at the same time as sending the notification to the Town Council of the place where the company has its seat. (Legislative Decree. No. 228/2001, Art. 4, p 3 and 4-bis) (Italian Republic, 2001).

According to the Regulation (EU) No. $1169 / 2011$, selling by means of distance communication is a technique of communication at a distance, that means "any means which, without the physical and simultaneous presence of the supplier and the consumer, may be used for the conclusion of the contract between these parties" (European Commission, 2011). World Wide Web, as for other sectors such as electronics, tourism and dressing, has become an excellent reference target for consumers searching for territorial or particular foods. Companies offering their goods for sale through Internet come under the definition of food companies and are subject to the regulations relevant to the food legislation. The EU Regulation (EU) No. 1169/2011 (European Commission, 2011), in Art. 14 sets down that in the case of prepacked foods offered for sale by means of distance communication all mandatory information shall be available in two distinct moments: 1) before the purchase is concluded (except the particular of date of minimum durability or the "use by" date) and shall appear on the material supporting the distance selling or be provided through other appropriate means clearly identified by the food business operator; 2) at the moment of delivery. For products marketed in this way it is not compulsory to mention the production lot or the Shipping Tracking Number as is set down in the Directive (EU) 2011/91 before the conclusion of the sale since they are instruments used for traceability which have no impact on the choice of the final consumer (European Commission, 2011). In the Official Gazette of the Italian Republic, Law 12 August 2016, No. 170 was published Art. 5 reports the power delegated for the adaptation of National legislation to European Laws (Regulation (EU) No. 1169/2011 and Directive (EU) No. 91/2011) (Italian Republic, 2016).

Regarding meat, meat-based preparations and unprocessed products based on frozen fish, at the moment of delivery the information must be supplied regarding the date of freezing or the first freezing for products that have been frozen more than once (Regulation (EU) No. 1169/2011, p 6, Attachment III) (European Commission, 2011).

In the case of non-prepacked foods offered for sale by means of distance communication the particulars required under Art. 44 shall be made available in accordance with $\mathrm{p} 1$ of this Art. p 1, letter (a) of Regulation (EU) No.1169/2011: “(a) mandatory food information, except the particulars provided in point (f) of Art. 9 (1) [my note. The date of minimum durability or the "use by" date], shall be available before the purchase is concluded...; (b) all mandatory particulars shall be available at the moment of delivery". "Any ingredient or processing aid listed in Annex II or derived from a substance or product listed in Annex II causing allergies or intolerances used in the manufacture or preparation of a food and still present in the finished product, even if in an altered form" shall be mandatory.

For the food products sold using this technique of communication at a distance, the subject who must supply the compulsory information on these products before the conclusion of the sale is the holder of the web site, while the responsibility for the information described on the label is the food business operator whose name is on the label. In any case the general principles remain unaffected of electronic marketing referred in the Directive (EC) 2000/31 as they are set out in each member State and applied by the community and national law (European Commission, 2000).

\section{Automatic vending machines and automated marketing premises}

Sales using vending machines, which usually dispense food and drinks which are not pre-packaged (tea, coffee in cup), are more frequently in automated selling points where foods are sold pre-packaged (snacks and drinks). For these foods (pre-packaged) the information set down as compulsory on the label must be made available to the consumers before they make their choice because it is selling at a distance also in this case (Regulation (EU) No. 1169/2011, Art. 14, point 3) (European Commission, 2011). For those not pre-packaged, the regulations are valid as in $\mathrm{p} 2$, Art. 15 of the Legislative Decree No. 109/1992, which includes the name of the product and the list of the ingredients, as well as the name or trade name and address of managing carrier of vending machine (Italian Republic, 1992). Unlike raw milk meant for direct human consumption, for which specific reference regulations exist, (SRA of 25/01/2007 - No 5/CSR) (Italian Republic, 2007), for other non-pre-packaged foods (e.g. Instant drinks or instant delivery) Art. 44 of the Regulation (EU) No. 1169/2011 is applied according to which allergens must be listed that may be contained in the product (European Commission, 2011). The European Commission has made it clear that mandatory information on the food need not be supplied before the sale (in Italy is applied by Circular No. 381060 05/12/2016 of Ministry of Economic Development) (Italian Republic, 2016). However, given the special features of this means of distribution, the member States may, through specific national regulations, see to conveying the information on allergens and any other compulsory information on foodstuffs before selling, for example using a sign placed at the automatic vending machine. Lastly, this type of product, except for national regulations, may be considered exempt from the obligation of displaying the nutritional declaration.

\section{Labelling and presentation of the products}

Agro-food products destined for direct sales must display information for the final consumer, according to their presentation (bulk or pre-packaged) with respect to general and special reference regulations. In 
fact, as well as the regulations referred to in the Regulation (EU) No. 1169/2011 and the Legislative Decree No. 109/1992 and later modifications where it is still applicable (bulk and semi-processed products), some sectorial regulations have to be considered (meats, fish products etc.) as well as the metrological regulations (European Commission, 2011; Italian Republic, 1992).

As regards "fresh and processed fruit and vegetable products" the reference regulation is represented by the Regulation (EU) No. 1308/2013 and the Regulation (EU) No. 543/2011 (European Commission, 2011; 2013). For fruit and vegetables sold in bulk, as well as the origin (the country they come from) the following information must be displayed: price per Kilo; category; size; variety and species. On the other hand, for fruit and vegetables sold pre-packaged, the following must be displayed on the packets: category; size; variety and species; tare weight of the packaging or weight at the origin; name and address of the packager and/or delivery agent; production lot and/or packaging, at the discretion of the FBO, using alphanumeric code preceded by the letter L (Regulation (EU) No. 1308/2013; Regulation (EU) No. 543/2011) (European Commission, 2011; 2013).

Pre-packaged fresh meat of the pork, lamb, goat and poultry species, as well as respecting the general obligations for labelling, must display information on the country of origin or the place of provenance (Regulation (EU) No. 1337/2013) (European Commission, 2013b). Further regulations are set down for beef meats (Regulation (EU) No. 1760/2000; Law 171/1964) and for poultry meats (Legislative Decree No 202/2011; Regulation (EC) No. 543/2008, Regulation (EC) No. 508/2009; Ministerial Order 26/08/2008) (European Commission, 2000; 2008; 2009; Italian Republic, 1964; 2008; 2011).

Food products placed directly on sale on the farm, since they are prepared at the place of production, may be presented in a "bulk" state and consequently for this type of presentation, it is sufficient to show the information on a special notice near the products displayed (e.g. jars of honey, jams etc.).

\section{Nutritional table}

Nutritional table - without prejudice to other Union provisions requiring a mandatory nutrition declaration, the nutrition declaration shall not be mandatory for the foods listed in Annex V of Regulation (EU) No. 1169/2001 as subsequently amended products produced by agricultural and artisan companies which fulfil the requirements for microenterprises which employs fewer than 10 persons and whose annual turnover and/or annual balance sheet total does not exceed EUR 2 million (Commission Recommendation 2003/361/EC) (European Commission, 2003) are exempt from this obligation, not only in the case of direct supplying to the consumers and the community according to Art. 2, Regulation (EC) No. 1169/2011, but also at a "local level" of the market and in the case of sales at a distance" (European Commission, 2011). Unprocessed products are also interesting which are made up of only one ingredient or a single category of ingredients e.g. honey, eggs, sacks of potatoes or apples, fruit and vegetables of III and IV range, fish preparations for frying or for sauces, bulk foods or wrapped in packages or containers where the largest surface measures less than 25 sq. cm.

\section{Auto-control system on farms}

Farmers, as FBO who carrying out any stage of food production after primary production and those associated operations, and in compliance with general hygiene requirements listed in Annex II of Regulation (EC) No. 852/2004 and any specific requirements provided for in Regulation (EC) No. 853/2004, shall put in place, implement and maintain a permanent procedure or procedures based on the Hazard Analysis and Critical Control Points (HACCP) principles (European Commission, 2004; 2004b). Otherwise, in primary production, controlling, and consequently the food safety, may be carried out only with the application of the prerequisite programs (PRPs) which include, among other things, correct good hygienic practices (GHP), good manufacturing practices (GMP) and good agricultural practices (GAP). In fact, unlike primary products (fruit and vegetables, woodland products, farmed and hunted animals etc.) for which particular critical issues are not highlighted, for products undergoing later handling and processing it is necessary to employ procedures based on the principles of the HACCP system. (Regulation (EC) No. $852 / 2004$, Art. 5) (European Commission, 2004).These principles, in fact, represent an indispensable instrument for FBO for identifying and controlling the hazards that may occur in foods and during food processing on their own premises. The European Commission in one of its announcements, considered it useful to supply directives concerning facilitations regarding setting up management systems for food safety, in certain food companies, regarding PRPs and the procedures based on the principles of the HACCP system. The scope of this document is to facilitate and harmonize the implementation of the European requisites regarding PRPs and HACCP (also contained in Regulations of the series UNI EN ISO) providing a practical guide which takes account of the size and nature of the premises and the connection between PRPs and HACCP. A food safety management system (FSMS) should be considered as a practical instrument for controlling the environment and the food production process and guaranteeing that the products are safe. It includes: pre-requisites and the HACCP system. The PRPs are not specific for a certain danger, but are applied in a generalized way. GHP, together with GMP and traceability provisions are considered as PRPs which, together with the procedures based on the HACCP principles, must result in an integrated FSMS for each business operator (after primary production). When applying the PRPs the differences in terms of risk, which make up the basis for evaluating the introduction of the flexibility in applying these programs, must be taken into account. As regards the HACCP system, the procedures based on this system should be flexible enough to be able to be applied in any situation. The concept of flexibility has already been brought up by the Regulation (EC) No. 852/2004 (Art. 5, p 15) (European Commission, 2004), which has the aim of guaranteeing the proportionality of the controlling measures, adapting them to the nature and size of the premises, without omitting correct management of the risk and without compromising the food safety. On this subject, it is also useful to remember the opinion of the European social and economic committee on the topic "Hygiene regulations and processing artisan companies" (2006/C - 65/25), which draws attention to the importance of the union between the small food companies and the micro-companies and rural development; and how these, more than the others, use artisan and/or traditional production processes. When there is no preparation activity or there is simple handling activity (harvesting vegetables, ground vegetables etc.) it is considered that the analysis of the hazards and the management of the possible risks may be carried out through setting up and applying, on the part of the farmer, controlling procedures based on the application of basic hygienic measures (programs of pre-requisites) and correct keeping of adequate documentation and registration

If there are operations such as meat processing, cheese making, food-trucks and retail sales where easily perishable food is prepared, as well as the PRPs regarding food hygiene, it is considered indispensable to identify all the important hazards that may 
be found within the various types of handling and define the control systems of the same, the monitoring operations of the processing and preserving procedures of the food (correct functioning of the cooking and freezing equipment) with a simplified approach to comply with the other principles of the HACCP system. In small companies it may be sufficient for the analysis of the hazards contained in the HACCP plan to describe simply and practically the control methods for the hazards without necessarily going into detail on the nature of the hazards themselves. To identify the CCP, the various food hazards can be controlled either by implementing only the PRPs or in combination with the application of certain operational PRPs (simple visual check of the temperature of the equipment, noting only the irregularities shown and the corrective measures taken). It must be underlined, however, that flexibility regarding analysis of dander cannot be directly linked to the dimensions of the company and it is not appropriate even when the company is small: this is the case, for example, of companies where food is produced (cooked or raw) destined for categories of vulnerable consumers; or when controls are carried out for allergens in products declared free of allergens.

\section{Conclusions}

The new course of EU politics is more and more orientated towards promotion of small agro-zootechnical productions from a point of view of sustainability and safeguarding the ties with the territory and with the other resources which contribute to the identity of the products themselves (e.g. Regulation (EU) No. 1151/2012) (European Commission, 2012). Not least is the possibility of creating work and occupation and adequately counteracting the phenomenon of the depopulation of the countryside, encouraging the return to agricultural activities on the part of young people. The same legislation urges farmers to promote a form of safeguarding of the environment by assuring them "to the extent possible" protection of primary products from contamination coming from the air, the earth and the water; through the correct use of veterinary medicines, additives for animal foods, fertilizers and plant protection products and biocides; and also the correct management and elimination of wastes (attachment I, Regulation (EC) No. 852/2004) (European Commission, 2004). This trend, together with the national directions, may represent a support even for small local farms which, taking advantage of simplified procedures consistent with the objectives of flexibility of the community regulations, may take part in the promotion of agricultural markets managed directly by the farmers (Short distribution chain or short circuit).

\section{References}

Accordo tra il Governo, le Regioni e delle Province autonome di Trento e Bolzano e le Autonomie locali sul documento recante: "Linee guida applicative del Regolamento No. 853/2004/CE del Parlamento europeo e del Consiglio sull'igiene dei prodotti di origine animale". Rep. Atti No. 253/CSR del 17 dicembre 2009.

Accordo tra il Governo, le Regioni e delle Province autonome di Trento e Bolzano e le Autonomie locali sul documento recante: "Linee guida applicative del Regolamento No. 852/2004/CE del Parlamento europeo e del Consiglio sull'igiene dei prodotti alimentari'. Rep. Atti No. 59/CSR del 29 aprile 2010.

Circolare 5 dicembre 2016, No. 381060. Ministero dello Sviluppo Economico. Chiarimenti interpretativi forniti dalla Commissione europea riguardo al coordinamento delle disposizioni di cui al decreto legislativo 27 gennaio 1992, No. 109, con le disposizioni del Regolamento (UE) No. 1169/2011, relativo alla fornitura di informazioni sugli alimenti ai consumatori. Gazzetta Ufficiale Serie Generale No. 2 del 03 gennaio 2017.

Commission Implementing Regulation (EU) No. 534/2011 of 31 May 2011 establishing the standard import values for determining the entry price of certain fruit and vegetables Official Journal L 146/13.

Commission Implementing Regulation (EU) No. 29/2012 of 13 January 2012 on marketing standards for olive oil Official Journal L 12/14.

Commission Implementing Regulation (EU) No. 1337/2013 of 13 December 2013 laying down rules for the application of Regulation (EU) No. 1169/2011 of the European Parliament and of the Council as regards the indication of the country of origin or place of provenance for fresh, chilled and frozen meat of swine, sheep, goats and poultry Official Journal L 335/19.

Commission Recommendation of 6 May 2003 concerning the definition of micro, small and medium-sized enterprises Official Journal 2003 L 124/36.

Council Regulation (EEC) No. 822/87 of 16 March 1987 on the common organization of the market in wine Official Journal L 84/1.

Council Regulation (EEC) No. 1907/90 of 26 June 1990 on certain marketing standards for eggs Official Journal OJ L 173, 6.7.1990.

Council Regulation (EC) No. 2597/97 of 18 December 1997 laying down additional rules on the common organization of the market in milk and milk products for drinking mil Official Journal L 351.

Council Regulation (EC) No. 1513/2001 of 23 July 2001 amending Regulations No $136 / 66 /$ EEC and (EC) No. 1638/98 as regards the extension of the period of validity of the aid scheme and the quality strategy for olive oil Official Journal L 201.

Council Regulation (EC) No. 1234/2007 of 22 October 2007 establishing a common organisation of agricultural markets and on specific provisions for certain agricultural products (Single CMO Regulation) Official Journal L 299/1.

Council Regulation (EC) No. 1099/2009 of 24 September 2009 on the protection of animals at the time of killing (Text with EEA relevance) Official Journal 303/1.

Commission Regulation (EC) No. 543/2008 of 16 June 2008 laying down detailed rules for the application of Council Regulation (EC) No. 1234/2007 as regards the marketing standards for poultrymeat Official Journal L 157.

Commission Regulation (EC) No. 508/2009 of 15 June 2009 amending Regulation (EC) No. 543/2008 laying down detailed rules for the application of Council Regulation (EC) No. 1234/2007 as regards the marketing standards for poultrymeat Official Journal L 151/28.

Commission Regulation (EC) No. 607/2009 of 14 July 2009 laying down certain detailed rules for the implementation of Council Regulation (EC) No. 479/2008 as regards protected designations of origin and geographical indications, traditional terms, labelling and presentation of certain wine sector products Official Journal L 193/60.

Conferenza permanente per i rapporti tra lo stato le regioni e le province autonome di Trento e Bolzano. Provvedimento 25 gennaio 2007. Intesa, ai sensi dell'articolo 8 , comma 6 , della legge 5 giugno 2003, n. 131, tra il Governo, le regioni e le province autonome di Trento e di Bolzano in materia di vendita diretta di latte crudo per l'alimentazione umana. Gazzetta Ufficiale Serie Generale del 13 febbraio 2007 - S. O. No. 36.

Decreto 22 luglio 2005. Ministero delle Attività Produttive. Disciplina della produzione e della vendita di taluni 
prodotti dolciari da forno. Gazzetta Ufficiale No. 177 del 1 Agosto 2005.

Decreto 20 novembre 2007. Ministero delle Politiche Agricole Alimentari e Forestali. Attuazione dell'articolo 1, comma 1065, della legge 27 dicembre 2006, No. 296, sui mercati riservati all'esercizio della vendita diretta da parte degli imprenditori agricoli. Gazzetta Ufficiale Serie Generale No. 301 del 29 dicembre 2007.

Decreto 23 dicembre 2013. Ministero delle Politiche Agricole Alimentari e Forestali. Disposizioni nazionali concernenti l'attuazione del regolamento di esecuzione (UE) No. 299/2013 della Commissione del 26 marzo 2013, recante modifica del regolamento (CEE) No. 2568/91, relativo alle caratteristiche degli oli d'oliva e degli oli di sansa d'oliva nonché ai metodi ad essi attinenti. Gazzetta Ufficiale della Repubblica italiana del 8 febbraio 2014 Serie generale - No. 32 .

Decreto Legge del 11 agosto 2014. Approvazione del manuale operativo per la gestione dell'anagrafe apistica nazionale, in attuazione dell'articolo 5 del decreto 4 dicembre 2009, recante: «Disposizioni per l'anagrafe apistica nazionale». Gazzetta Ufficiale Serie Generale del 16 dicembre 2014 No.291.

Decreto Legge 21 giugno 2013, No. 69. Disposizioni urgenti per il rilancio dell'economia. Gazzetta Ufficiale Serie Generale del 21 giugno 2013 No.144 Supplemento Ordinario No. 50.

Decreto Legislativo del 27 gennaio 1992, No. 109: Attuazione delle direttive (CEE) n. 395/89 e (CEE) No. 396/89, concernenti l'etichettatura, la presentazione e la pubblicità dei prodotti alimentari. Gazzetta Ufficiale del 17 febbraio 1992 - No. 39.

Decreto Legislativo del 16 febbraio 1993, No. 77. Attuazione della direttiva 90/496/CEE del Consiglio del 24 settembre 1990 relativa all'etichettatura nutrizionale dei prodotti alimentari. Gazzetta Ufficiale - Serie Generale del 24 marzo 1993 - No. 69.

Decreto Legislativo 31 marzo 1998 No. 114. Riforma della disciplina relativa al settore del commercio, a norma dell'articolo 4, comma 4, della legge 15 marzo 1997, No. 59. Gazzetta Ufficiale n. 95 del 24 aprile 1998 - No.80.

Decreto Legislativo 18 maggio 2001 No. 226. Orientamento e modernizzazione del settore della pesca e dell'acquacoltura, a norma dell'articolo 7 della legge 5 marzo 2001, No. 57. Gazzetta Ufficiale No. 137 del 15 giugno
2001 - No. 149.

Decreto Legislativo 18 maggio 2001 No. 228. Orientamento e modernizzazione del settore agricolo, a norma dell'articolo 7 della legge 5 marzo 2001, No. 57. Gazzetta Ufficiale No. $137 \mathrm{del}$ 15 giugno 2001 - No. 149.

Decreto Legislativo 20 febbraio 2004, No. 50. Attuazione della direttiva 2001/113/CE concernente le confetture, le gelatine e le marmellate di frutta, nonché la crema di marroni, destinate all'alimentazione umana. Gazzetta Ufficiale del 28 febbraio 2004 - No. 49. Decreto Legislativo 29 marzo 2004, No. 99. Disposizioni in materia di soggetti e attività, integrità aziendale e semplificazione amministrativa in agricoltura, a norma dell'articolo 1, comma 2 , lettere $d), f), g$ ), l), ee), della legge 7 marzo 2003, No. 38. Gazzetta Ufficiale del 22 aprile 2004 - No. 94.

Decreto Legislativo No. 202/2011. Relativo alla disciplina sanzionatoria delle violazioni ai regolamenti CE 1234/2007 e 543/2008, sulla commercializzazione e sul sistema volontario di etichettatura delle carni di pollame. Gazzetta Ufficiale del 6 dicembre 2011- No. 284.

Decreto Legislativo 9 gennaio 2012, No. 4. Misure per il riassetto della normativa in materia di pesca e acquacoltura, a norma dell'articolo 28 della legge 4 giugno 2010, No. 96. Gazzetta Ufficiale No. 26 del 1 febbraio 2012.

Decreto del Ministero delle Politiche Agricole, Alimentari e Forestali del 20 novembre 2007 "Linee di indirizzo per la realizzazione dei mercati riservati alla vendita diretta da parte degli imprenditori agricoli di cui all'articolo 2135 del CC, ivi comprese le cooperative di imprenditori agricoli". Gazzetta Ufficiale. Ufficio di controllo atti Ministeri delle attività produttive, registro No. 4, foglio No. 237.

Decreto del Ministero delle Politiche Agricole, Alimentari e Forestali del 11 dicembre 2009. Modalità per l'applicazione di disposizioni comunitarie in materia di commercializzazione delle uova, ai sensi dei regolamenti (CE) No. 1234/2007, del Consiglio e n. 589/2008, della Commissione e del decreto legislativo 29 luglio 2003, No. 267. Gazzetta Ufficiale No. 111 del 11 dicembre 2009.

Decreto del Ministero della Salute del 12 dicembre 2012. Informazioni obbligatorie e misure a tutela del consumatore di latte crudo o crema cruda, in attuazione dell'articolo 8, commi 6 e 9, del decreto-legge 13 settembre 2012, No. 158, recante
"Disposizioni urgenti per promuovere lo sviluppo del Paese mediante un più alto livello di tutela della salute" convertito, con modificazioni, dalla legge 8 novembre 2012, No. 189. Gazzetta Ufficiale No. 24 del 29 gennaio 2013.

Decreto del Presidente della Repubblica del 12 febbraio 1965, No. 162. Norme per la repressione delle frodi nella preparazione e nel commercio dei mosti, vini ed aceti. Gazzetta UfficialeSupplemento Ordinario No. 73, del 23 marzo 1965.

Decreto del Presidente della Repubblica 30 novembre 1998, No. 502. Regolamento recante norme per la revisione della normativa in materia di lavorazione e di commercio del pane, a norma dell'articolo 50 della legge 22 febbraio 1994, No. 146. Gazzetta Ufficiale Serie Generale No. 25 del 01 febbraio 1999.

Decreto del Presidente della Repubblica 9 febbraio 2001, No. 187. Regolamento per la revisione della normativa sulla produzione e commercializzazione di sfarinati e paste alimentari, a norma dell'articolo 50 della legge 22 febbraio 1994, No. 146. Gazzetta Ufficiale No. 117 del 22 maggio 2001.

Direttiva 2000/31/CE del Parlamento europeo e del Consiglio dell'8 giugno 2000 relativa a taluni aspetti giuridici dei servizi della società dell'informazione, in particolare il commercio elettronico, nel mercato interno («Direttiva sul commercio elettronico»). Gazzetta Ufficiale del 17 luglio 2000 - L 178.

EU Commission Notice on the implementation of food safety management systems covering prerequisite programs (PRPs) and procedures based on the HACCP principles, including the facilitation/flexibility of the implementation in certain food businesses of 30 July 2016- 2016/C 278/01.

Legge 25 giugno 1949, No. 353. Proroga dei contratti agrari di affitto dei fondi rustici, mezzadria, colonia parziaria e compartecipazione, nonché delle concessioni di terre incolte o mal coltivate. Gazzetta Ufficiale No. 153 del 7 luglio 1949.

Legge 9 febbraio 1963, No. 59. Norme per la vendita al pubblico in sede stabile dei prodotti agricoli da parte degli agricoltori produttori diretti. Gazzetta Ufficiale No. 44 del 16 febbraio 1963.

Legge 4 aprile 1964, No. 171. Modificazioni al regio decreto-legge 26 settembre 1930, No. 1458 sulla disciplina della vendita delle carni fresche o congelate. Gazzetta Ufficiale No. 92del 13 aprile 
1964.

Legge 4 luglio 1967, No. 580. Disciplina per la lavorazione e commercio dei cereali, degli sfarinati, del pane e delle paste alimentari. Gazzetta Ufficiale No. 189 del 29 luglio 1967.

Legge 27 gennaio 1968, No. 35. Norme per il controllo della pubblicità e del commercio dell'olio di oliva e dell'olio di semi. Gazzetta Ufficiale No. 37 del 12 febbraio 1968.

Legge 3 maggio 1982, No. 203. Norme sui contratti agrari. Gazzetta Ufficiale del 5 maggio 1982, No. 121. Con riferimento al presente provvedimento sono state emanate le seguenti circolari: I.N.P.S. (Istituto nazionale previdenza sociale): Circ. 26 giugno 1996, No. 132; Circ. 11 luglio 1996, No. 142; Circ. 18 settembre 1996, No. 182; Circ. 26 marzo 1997, No. 80.

Legge 16 dicembre 1985, No. 752. Normativa quadro in materia di raccolta, coltivazione e commercio dei tartufi freschi o conservati destinati al consumo. Gazzetta Ufficiale No. $300 \mathrm{del}$ 21 dicembre 1985.

Legge 10 febbraio 1992, No. 164. Nuova disciplina delle denominazioni d'origine dei vini. Gazzetta Ufficiale No. 47 del 26 febbraio 1992 - Supplemento Ordinario No. 42.

Legge 29 dicembre 1993, No. 580. Riordinamento delle camere di commercio, industria, artigianato e agricoltura. Gazzetta Ufficiale No. 7 del 11 gennaio $1994-$ S. O. No. 6.

Legge 24 dicembre 2004, No. 313. Disciplina dell'apicoltura. Gazzetta Ufficiale No. 306 del 31 dicembre 2004.

Legge 4 agosto 2006, No. 248. Conversione in legge, con modificazioni, del decretolegge 4 luglio 2006, No. 223, recante disposizioni urgenti per il rilancio economico e sociale, per il contenimento e la razionalizzazione della spesa pubblica, nonché interventi in materia di entrate e di contrasto all'evasione fiscale. Gazzetta Ufficiale No. 186 dell'11 agosto 2006 -S. O. No. 183.

Legge 9 agosto 2013, No. 98. Conversione in legge, con modificazioni, del decretolegge 21 giugno 2013, n.69, recante disposizioni urgenti per il rilancio dell'economia. Gazzetta Ufficiale No. 194 del 20 agosto 2013 -S. O. No. 63.

Legge 12 dicembre 2016, No. 238. Disciplina organica della coltivazione della vite e della produzione e del commercio del vino. Gazzetta Ufficiale No. 302 del 28 dicembre 2016.

Opinion of the European Economic and Social Committee on 'Hygiene rules and artisanal food processors' (2006/C 65/25) Official Journal C 65/141.

Ordinanza Ministeriale del 3 aprile 2002. Requisiti igienico-sanitari per il commercio dei prodotti alimentari sulle aree pubbliche. Gazzetta Ufficiale del 17 maggio 2002 No. 114.

Ordinanza Ministeriale del 26 agosto 2005. Gazzetta Ufficiale del 2 settembre 2005 No. 204.

Nota n. 39857 del 29 maggio 2015 inerente "Norma nazionale di elicicoltura biologica riconosciuta ai sensi dell'articolo 42 del Reg. (CE) No. 834/2007". Ministero delle Politiche Agricole Alimentari e Forestali.

Regulation (EC) No. 1760/2000 of the european Parliament and of the Council of 17 July 2000 establishing a system for the identification and registration of bovine animals and regarding the labelling of beef and beef productsand repealing Council Regulation (EC) No. 820/97 Official Journal L 204/1.

Regulation (EC) No. 178/2002 of the european Parliament and of the Council of 28 January 2002 laying down the general principles and requirements of food law, establishing the European Food SafetyAuthorityand laying down procedures in matters of food safety Official Journal L 031.

Regulation (EC) No. 852/2004 of the european Parliament and of the Council of 29 April 2004 on the hygiene of foodstuffs Official Journal L 139/1.

Regulation (EC) No. 853/2004b of the european Parliament and of the Council of 29 April 2004 laying down specific hygiene rules for food of animal origin Official Journal L 139/55

Regulation (EC) No. 110/2008 of the European Parliament and of the Council of 15 January 2008 on the definition, description, presentation, labelling and the protection of geographical indications of spirit drinks and repealing Council Regulation (EEC) No. 1576/89 Official Journal L39/16.

Regulation (EU) No. 1169/2011 of the European Parliament and of the Council of 25 October 2011 on the provision of food information to consumers, amending Regulations (EC) No. 1924/2006 and (EC) No. 1925/2006 of the European Parliament and of the Council, and repealing Commission Directive 87/250/EEC, Council Directive 90/496/EEC, Commission Directive 1999/10/EC, Directive 2000/13/EC of the European Parliament and of the Council, Commission Directives 2002/67/EC and 2008/5/EC and Commission Regulation (EC) No. 608/2004 (1) Official Journal L 304/18.

Regulation (EU) No. 1151/2012 of the European Parliament and of the Council of 21 November 2012 on quality schemes for agricultural products and foodstuffs Official Journal L 343.

Regulation (EU) No. 1308/2013 of the European Parliament and of the Council of 17 December 2013 establishing a common organisation of the markets in agricultural products and repealing Council Regulations (EEC) No. 922/72, (EEC) No. 234/79, (EC) No. 1037/2001 and (EC) No. 1234/2007 Official Journal L 347 .

Regulation (EU) No. 251/2014 of the European Parliament and of the Council of 26 February 2014 on the definition, description, presentation, labelling and the protection of geographical indications of aromatised wine products and repealing Council Regulation (EEC) No. 1601/91 Official Journal L 84/14. 